\title{
DESAIN MODEL AKSELERASI MANAJEMEN SAMPAH SEKOLAH DASAR SEBAGAI UPAYA PEMBENTUKAN SEKOLAH BERBUDAYA LINGKUNGAN DAN PEMBERDAYAAN EKONOMI
}

\author{
Lita Dwipasari ${ }^{1^{*}}$ \\ ${ }^{1}$ Fakultas Ekonomi dan Bisnis Universitas Merdeka Malang \\ *lita_dwipasari@yahoo.com
}

\begin{abstract}
Abstact
Bank Sampah in Malang is an arm of government to manage waste. The more increasing number of quality garbage collected, the greater the customer's account at the Bank. Bank Sampah will help meet the waste demand of recycling plant. Elementary school is the customer target groups Bank Sampah Malang. They have many obstacles in its waste management activities. Bank Sampah and the Department of Education in Malang has been providing direction and some facilities for waste management in elementary schools.

This study was conducted to produce a acceleration model of waste management Elementary School. Making design through several phases: analysis of the situation (questionnaire, observation and documentation). Structured questionnaire based on analysis Input-ProcessOutput (IPO). Evaluation model made through brainstorming to generate empirical models. Socialization and accompaniment is done at 3 elementary schools. Field testing is conducted through a quasi method because there are treatment methods for sample (Elementary School) . Final testing of this model is the descriptive analysis (changes of primary account number and environmental changes of elementary school) and inferential analysis by performing the Wilcoxon paired sample test (for non-parametric statistics).
\end{abstract}

Key words: Bank Sampah, Acceleration Model, Elementary School

\section{PENDAHULUAN}

Konsep pengelolaan sampah secara modern yaitu dengan konsep $3 \mathrm{R}$ (Reduce,Reuse dan Recycle) yang dicanangkan pemerintah Indonesia sudah mulai menunjukkan hasilnya. Sampah memang perlu menjadi perhatian yang serius karena sampah merupakan masalah tersendiri yang bila tidak ditangani dengan baik akan menimbulkan masalah penyakit, masalah sosial dan pencemaran lingkungan, sebaliknya apabila sampah dapat dikelola dengan baik maka dapat mendatangkan perubahan lingkungan dan pendapatan ekonomi. Bank Sampah di beberapa kota di Indonesia adalah salah satu lembaga yang dibentuk pemerintah untuk mengelola sampah di kota dengan konsep 3R tersebut.
Lembaga ini mengelola sampah dari hulu (sumber sampah) dan hilir (pemasaran) sehingga sampah memiliki nilai ekonomi untuk meningkatan pendapatan masyarakat.

Pada Bank Sampah yang berada dikota Malang, nasabah dibagi dalam 4 kelompok binaan yaitu kelompok masyarakat (RT/RW), kelompok sekolah, kelompok perdagangan dan kelompok perusahaan . Pada November 2015 terdapat 303 unit BSM kelompok masyarakat (aktif 90\%), 174 kelompok sekolah (aktif 60\%), 24 instansi , 542 individu dan 14 lapak/pengepul. Sedangkan jumlah sampah yang terangkut BSM rata-rata 3 ton perhari (BSM, 2015). Padahal jumlah sampah yang dihasilkan 6,5 ton perhari.

Untuk kelompok binaan sekolah khususnya Sekolah Dasar maka BSM 
didukung oleh Diknas kota Malang, sehingga terjalin MOU antara BSM dengan pihak Sekolah Dasar (2011). Kelompok ini sangat potensial untuk pendidikan generasi muda dalam hal merubah perilaku terhadap sampah. Namun dalam kenyataan semakin lama partisipasi kelompok sekolah semakin menurun karena banyaknya kendala dilapangan. Data total jumlah kelompok sekolah sampai 2015 terdapat 60\% jumlah sekolah yang tidak aktif, data Sekolah Dasar aktif adalah 131 Sekolah Dasar aktif kini hanya menjadi 14 Sekolah Dasar aktif.

Sekolah aktif adalah sekolah yang masih melakukan transaksi dengan BSM dan ditunjukkan dengan rekening yang aktif. Dari data diketahui pula bahwa Sekolah Dasar adalah binaan yang paling banyak namun secara drastis mengalami penurunan. Jika kendala-kedala yang terjadi pada Sekolah Dasar tidak diatasi maka manajemen sampah hanya merupakan gerakkan moral saja bagi sekolah yang tidak berlanjut. Pelatihan dan pemberian fasilitas menjadi sia-sia dan yang lebih parah lagi adalah pendidikan perilaku bersih dan peduli lingkungan dan peduli sampah menjadi tidak tercapai. Selain itu tidak adanya pendapatan untuk sekolah, yang ada adalah sampah hanya bisa menjadi biaya yang harus dikeluarkan (retribusi sampah), pengurangan penumpukkan sampah kota oleh sekolahpun menjadi tidak terlaksana. Kelompok Sekolah Dasar membutuhkan petunjuk tekhnis pelaksanaan kegiatan manajemen sampah sekolah agar dapat melakukan pemberdayaan secara mandiri dalam mengelola sampahnya.

Tujuan kegiatan penelitian ini adalah : 1) Memberikan model Akselerasi manajemen sampah dilingkungan Sekolah Dasar untuk membantu mengatasi kendala dilapangan., 2) Membantu sekolah memiliki aktivitas yang terkait dengan kurikulum yang akan berdampak bagi lingkungan dan secara ekonomi 3) Membangun sekolah membangun sikap "terpaksa" membuang sampah menjadi "sadar sampah" dilingkungan generasi muda dalam hal ini siswa sekolah dasar.

\section{Kurikulum Sekolah Dasar}

Sekolah dasar adalah jenjang paling dasar pada pendidikan formal di Indonesia. Sekolah dasar ditempuh dalam waktu 6 tahun, mulai dari kelas 1 sampai kelas 6. Saat ini murid kelas 6 . Siswa sekolah dasar umumnya berusia 7-12 tahun. Di Indonesia, setiap warga negara berusia 7-15 tahun wajib mengikuti pendidikan dasar, yakni sekolah dasar (atau sederajat) 6 tahun dan sekolah menengah pertama (atau sederajat) 3 tahun. Sekolah dasar diselenggarakan oleh pemerintah maupun swasta. Sejak diberlakukannya otonomi daerah pada tahun 2001, pengelolaan sekolah dasar negeri (SDN) di Indonesia yang sebelumnya berada di bawah Departemen Pendidikan Nasional, kini menjadi tanggung jawab pemerintah daerah kabupaten/kota. Sedangkan Departemen Pendidikan Nasional hanya berperan sebagai regulator dalam bidang standar nasional pendidikan. Secara struktural, sekolah dasar negeri merupakan unit pelaksana teknis dinas pendidikan kabupaten/kota.

Pada tahun 2015 terdapat masa transisi penggunaan kurikulum di Sekolah Dasar, yaitu kurikulum 2013 (tematik integratif) dan kurikulum 2006. Kurikulum 2013 secara bertahap dan terbatas telah diterapkan pada tahun pelajaran 2013/2014. Penerapannya dilakukan pada 2.598 sekolah dasar percontohan. Selain sekolah percontohan tersebut, sekolah yang baru satu semester menerapkan kurikulum 2013 akan tetap menggunakan kurikulum 2006. Kurikulum 2013 benar-benar diterapkan setelah sekolah siap. Untuk sementara Sekolah Dasar akan kembali menggunakan Kurikulum 2006.

\section{Kerangka Dasar Kurikulum 2013 bagi Sekolah Dasar}

Kurikulum 2013 dirancang dengan beberapa karakteristik diantaranya adalah bahwa sekolah merupakan bagian dari masyarakat yang memberikan pengalaman belajar terencana dimana peserta didik menerapkan apa yang dipelajari di sekolah ke masyarakat dan memanfaatkan masyarakat sebagai sumber belajar. Sekolah harus 
mampu mengembangkan sikap, pengetahuan, dan keterampilan siswa sehingga siswa mampu menerapkannya dalam berbagai situasi di sekolah dan dimasyarakat. Kurikulum 2013 yang disusun bertujuan untuk mempersiapkan manusia Indonesia agar memiliki kemampuan hidup sebagai pribadi dan warga negara yang beriman, produktif, kreatif, inovatif, dan afektif serta mampu berkontribusi pada kehidupan bermasyarakat, berbangsa, bernegara dan peradaban dunia. Landasan filosofis dalam pengembangan kurikulum menentukan kualitas peserta didik yang akan dicapai kurikulum, sumber dan isi dari kurikulum, proses pembelajaran, posisi peserta didik, penilaian hasil belajar, hubungan peserta didik dengan masyarakat dan lingkungan alam di sekitarnya. Kurikulum 2013 dikembangkan dengan landasan filosofis yang memberikan dasar bagi pengembangan seluruh potensi peserta didik menjadi manusia Indonesia berkualitas yang tercantum dalam tujuan pendidikan nasional.

Penerapan kurikulum dalam proses pembelajaran siswa Sekolah Dasar menggunakan metode tematik integratif. Metode ini adalah menggabungkan materi tidak berdasarkan matakuliah tertentu namun mengintegrasikan seluruh mata pelajaran, sehingga akan memberikan materi yang bermakna bagi siswa.Tema adalah pokok pemekiran atau gagasan yang menjadi pokok bahasan. Tema akan menjadi penggerak bagi mata pelajaran lainnya. Pada masing-masing kelas akan diberikan banyak tema, dan umumnya ada 8 tema untuk tiap jenjang kelas. Gurulah yang akan menetapkan tema dan memilih durasi waktunya. Satu tema yang dipilih guru dapat diintegrasikan pada 6 matapelajaran wajib yaitu agama, bahasa Indonesia, matematika, seni budaya, PPkn, Pendidikan jasmani dan kesehatan.metode tematik mengharuskan siswa aktif dalam pembelajaran dan melakukan observasi dalam setiap tema yang menjadi bahasan. Sampah dan lingkungan dapat menjadi tema bahasan bagi setiap tingkatan kelas bagi siswa Sekolah dasar yang akan mencakup pada 6 mata pelajaran pokok.

\section{Sekolah Berbudaya Lingkungan}

Sekolah berbudaya lingkungan (Adiwiyata) adalah salah satu program Kementrian Negara Lingkungan Hidup dalam rangka mendorong terciptanya pengetahuan dan kesadaran warga sekolah dalam upaya pelestarian lingkungan hidup. Dalam program ini diharapkan setiap warga sekolah ikut terlibat dalam kegiatan sekolah menuju lingkungan yang sehat serta menghindari dampak lingkungan yang negatif. Dalam pelaksanaannya Kementrian Negara Lingkungan Hidup bekerjasama dengan para stakeholder, menggulirkan Program Adiwiyata ini.

Kata adiwiyata berasal dari bahasa Sansekerta "adi" dan "wiyata". "adi" mempunyai ,makna : besar, agung, baik, ideal atau sempurna. Wiyata mempunyai makna : tempat dimana seseorang mendapat ilmu pengetahuan, norma dan etika dalam berkehidupan sosial. Jadi, adiwiyata mempunyai pengertian atau makna : Tempat yang baik dan ideal dimana dapat diperoleh segala ilmu pengetahuan dan berbagai norma serta etika yang dapat menjadi dasar manusia menuju terciptanya kesejahteraan hidup kita dan menuju kepada cita-cita pembangunan berkelanjutan. Memahami makna sekolah berwawasan lingkungan yang seharusnya adalah berbuat untuk menciptakan kualitas lingkungan sekolah yang kondusif, ekologis, lestari secara nyata dan berkelanjutan, tentunya dengan cara-cara yang simpatik, kreatif, inovatif dengan menganut nilai-nilai dan kearifan budaya lokal.

Sekolah berwawasan lingkungan (adiwiyata) bukan hanya tampilan fisik sekolah yang hijau/rindang, tetapi Wujud sekolah yang memiliki program dan aktivitas pendidikan mengarah kepada kesadaran dan kearifan terhadap lingkungan hidup. Program pendidikan dikemas secara partisipatif penuh, percaya pada kekuatan kelompok, mengaktifkan dan menyeimbangkan Feeling, Acting, dan Thinking, sehingga tiap individu bisa merasakan nilai keagungan inisiasinya. Secara konsep kelompok didorong untuk mampu melahirkan visi bersama dengan memahami apa yang menjadi makna 
(Definisi), menemukan dan mengapresiasi apa yang telah ada dan tentunya itu terbaik (Discovery), menemukan apa yang semestinya ada (Dream), menstrukturkan apa yang ada (Design) dan merawatnya hingga menjadi ada (Destiny), sehingga hasilnya akan melampaui dari apa yang dinginkan dan sangat sinergi dengan konteks realitas yang ada dalam kehidupan sekolah.

\section{Manajemen Sampah}

Konsep pengelolaan dan pengolahan sampah di negara-negara maju sudah dengan konsep modern. Seperti di negara Jepang, mereka melakukan daur ulang untuk sampah secara besar-besaran, dengan melibatkan seluruh masyarakat, lengkap dengan undangundang. Para konsumen bertanggung jawab untuk memilah sampah masing-masing (sampah basah, sampah kering yang dipilahpilah lagi menjadi botol gelas dan plastik, kaleng aluminium, dan kertas), sedangkan pemerintah daerah bertanggung jawab mengorganisir sampah-sampah itu untuk diserahkan ke pabrik pendaur ulang (Udi, 2009). Di Amerika mempunyai sistem pengelolaan dan pengolahan sampah yang berbeda di tiap daerah, salah satu contoh daerah yang mempunyai sistem pengelolaan dan pengolahan sampah modern yaitu di Monroe County, di daerah ini dikenal dengan nama "Monroe County Solid Waste Management District". Tempat ini dikelola langsung oleh pemerintah setempat dengan misi seperti menjadi tempat pembuangan akhir yang menggunakan metode pengolahan sampah landfill dan insinerator, memberikan pendidikan lingkungan kepada masyarakat, melakukan daur ulang sampah, membuat suatu bisnis persampahan, dan perkumpulan masyarakat untuk membahas perkembangan dari pengolahan sampah tersebut (Monroe County Solid Waste Management District, 2006). Konsep bisnis persampahan di negara maju ada beberapa macam, sepert adanya pasar atau tempat penjualan sampah-sampah yang sudah di daur ulang dan akan didiskusikan dalam organisasi Green Business Network, yang dapat membuka peluang usaha dan membuka lapangan pekerjaan bagi setiap elemen masyarakat.

\section{Bank Sampah Malang (BSM)}

Bank sampah Malang didirikan dengan badan hukum koperasi pada tanggal 26 Juli 2011. Dan diaktekan dinotaris tanggal 12 Agustus 2011, serta pengesahan dari Wali kota Malang tanggal 16 Agustus 2011. Adapun maksud dan tujuan BSM adalah sebagai berikut.

a. Membantu pemerintah kota mengurangi volume sampah yang ada dikota Malang terutama di TPS danNTPA.

b. Mengaktifkan peran serta masyarakat mulai dari level bawah RT/RW, Lembaga yang ada di kota Malang, pasar/perdagangan, perkantoran dan hotel

c. Membantu mengatasi masalah kesehatan lingkungan yang diakibatkan oleh sampah

d. Menciptakan lapangan kerja baru bagi masyarakat

e. Memberi kesadaran masyarakat tentang memilah, mengelola sampah dan menjadikannya sebagai barang yang bernilai ekonomis guna memberikan tambahan penghasilan.

f. Memberikan pinjaman atau pembelian sembako pada masyarakat yang membutuhkan dengan pengembalian dan pembayaran dalam bentuk sampah yang layak jual. 
METODE

\section{Rancangan Kegiatan :}

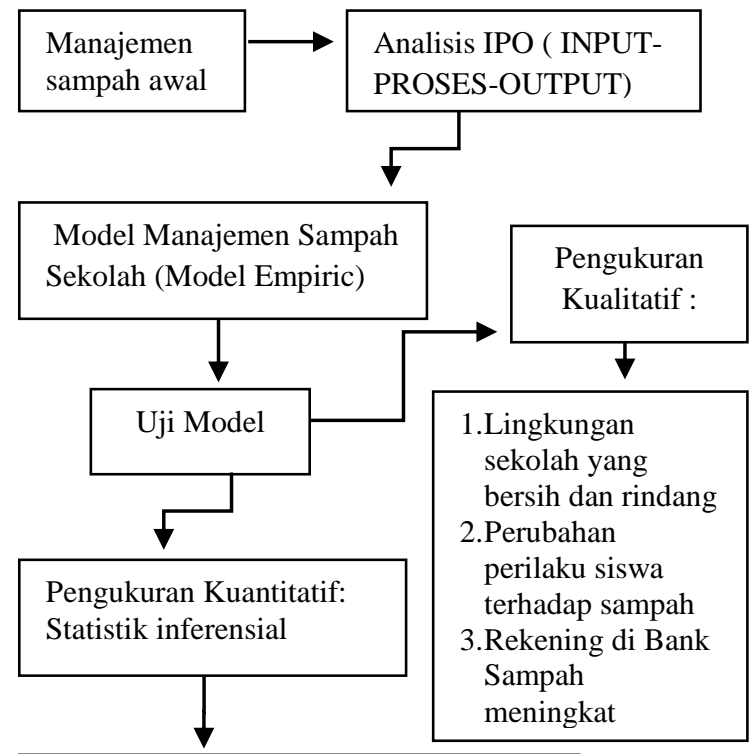
A. Pretest
B. Treatmeant (sosialisasi, pengarahan sesuai model)
C. Posttest

Uji hipotesis dua sample berpasangan

Gambar 1. Rancangan kegiatan

\section{Populasi dan Sampel}

Dari sekolah Dasar yang melakukan MOU dengan BSM diambil sebanyak 28 responden yang terdiri dari 11 sekolah aktif dan 16 sekolah kurang aktif dengan perincian 11 sekolah dengan saldo dibawah Rp.100.000,- dan 5 sekolah tidak aktif dengan saldo nol. Responden penelitian ini adalah Sekolah dasar yang diwakili oleh seseorang yang merupakan koordinator/pelaksana kegiatan manajemen sampah /lingkungan di sekolah, baik itu seorang kepala sekolah, guru maupun karyawan. Sedangkan untuk uji model empiric digunakan 3 SD dari sample tersebut.

\section{Tehnik Analisis}

Sesuai dengan kebutuhan dalam penelitian ini maka dilakukan empat tahapan kegiatan yaitu 1) studi pendahuluan, 2) perancangan model pembelajaran, 3) pengembangan model berupa kegiatan penilaian draft model, revisi draft model berdasarkan hasil penilaian, ujicoba dan revisi draf model, 4)Uji model. Dalam pelaksanaannya, penelitian ini diawali dengan melakukan studi pendahuluan untuk menemukan draft model berdasarkan karakteristik yang ditemukan. Selanjutnya draft model dikembangkan melalui ujicoba. Studi Pendahuluan dibagi menjadi dua yaitu kajian pustaka yang digunakan untuk memilih sample berdasarkan data dalam dokumen BSM dan kajian lapangan yang menggunakan questioner, wawancara, curah pendapat, observasi dan dokumentasi.Uji Model dilakukan dengan mensosialisasikan model kepada Sekolah Dasar baik yang aktif maupun tidak aktif. Model hasil ujicoba disebut model empirik yaitu model yang akan diimplementasikan. Selanjutnya model empirik diujicobakan untuk mengetahui keefektifan dan keterbatasannya. Model empirik akan diujikan dengan 3 Sekolah Dasar yang kurang aktif dan tidak aktif. Hasil uji model empirik disebut sebagai model teruji (model akhir) yaitu model manajemen sampah bagi Sekolah Dasar. Dalam pengujian ini dipilih 3 Sekolah Dasar untuk eksperimen. Desainnya penelitian menggunakan one group pretest-posttest (MC Milan \&Schumacher,2001) seperti digambarkan berikut ini :

\section{One group-posttest Design}

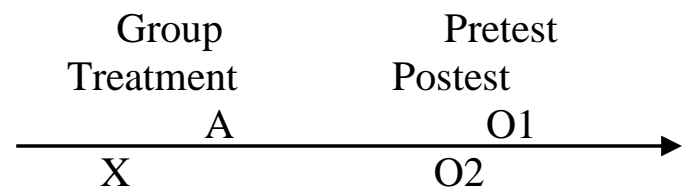

Gambar 2. Rancangan eksperimen

Keterangan :

$\mathrm{A}=$ Kelompok eksperimen

$\mathrm{O} 1=$ Test awal (pretest)

$\mathrm{O} 2=$ Test akhir (posttest)

$\mathrm{X}=$ Model skselerasi manajemen sampah

Instrumen yang digunakan setiap tahapan uji model adalah :

1. Menetapkan sekolah sasaran (responden) 
2. Identifikasi data awal responden yaitu checklist material yang ada

3. Sosialisasi model

4. Pelaksanaan eskperimen dan penyusunan instrumen pengamatan.

5. Observasi (pengamatan) terhadap performance percobaan akan dilakukan secara periodik sesuai jadwal yang telah diatur. Record book memasukkan data dengan segera dengan data yang paling primer.

6. Analisa dan interprestasi hasil percobaan

Pada tahap ini diperoleh data kuantitatif dan kualitatif. Data kualitatif diperoleh dari hasil test tindakan berupa peningkatan jumlah rekening di BSM dan perubahan perilaku,lingkungan sekolah yang bersih dan rindang. Sedangkan data kuantitatif diperoleh dari skor tindakan pada test pretest dan postest pada kelompok eksperimen. Data tersebut dianalisis dengan menggunakan uji statistik yaitu dengan analisis uji dua sampel dependen (berpasangan) menggunakan SPSS versi 16.

\section{Definisi Operasional Variabel :}

Model Akselerasi Manajemen sampah sekolah adalah model yang dapat membantu mempercepat peningkatan pendapatan sekolah dan kelancaran serta kestabilan pengumpulan sampah. Sehingga model akselerasi ini keberhasilannya diukur pada: a) Kemampuannya memperlancar pengumpulan sampah, b) Kemampuannya meningkatkan kebersihan lingkungan

Sekolah Berwawasan Lingkungan adalah sekolah yang mengaplikasikan pemeliharaan lingkungan dalam keseharian pembelajarannya. Sehingga pada akhirnya sekolah mampu mengelola sampahnya sendiri, baik sampah basah maupun sampah kering.

Pemberdayaan ekonomi adalah peningkatan kemampuan untuk melaksanakan kegiatan manajemen sampah sekolah dan adanya peningkatan pendapatan yang riil bagi nasabah kelompok sekolah. Pendapatan tersebut baik digunakan oleh sekolah, murid maupun warga sekolah lainnya (pembersih)

\section{HASIL DAN PEMBAHASAN}

Hasil olah data dari questioner yang disusun berdasarkan analisa IPO (inputProses-Output) dan membandingkan hasilnya antara sekolah aktif, kurang aktif dan tidak aktif (sebagaimana dalam tabel 2), maka didapat gambaran sebagai berikut:

1. Sekolah aktif memiliki ruang penyimpanan sampah yang memadai, sedangkan yang kurang aktif atau tidak aktif memilikinya pula (lebih dari $50 \%$ ), walaupun keadaan yang ada belum sesuai dengan yang diisyaratkan yaitu terlalu kecil atau lahan berada didalam sekolah sehingga tidak mudah bagi BSM untuk mengambil sampahnya.

2. Kegiatan manajemen sampah disekolah memerlukan kreativitas dan motivasi tersendiri karena sekolah aktif dan kurang aktif maupun tidak aktif memperolah sosialisasi dan pengarahan yang sama. Namun kemudian sekolah aktif berusaha mengembangkannya.

3. Sekolah yang mendapat penghargaan adiwiyata belum tentu melaksankan kegiatan manajemen sampah. Namun sekolah yang melakukan manajemen sampah pasti sekolah yang sudah pernah mendapatkan penghargaan adiwiyata.

4. Manajemen sampah disekolah memerlukan kejelasan prosedur dan tugas bagi para guru.

Tabel 2. Deskripsi Responden

\begin{tabular}{|c|c|c|c|c|c|c|c|}
\hline \multirow{2}{*}{\multicolumn{2}{|c|}{$\begin{array}{c}\text { KETERANGAN } \\
\begin{array}{c}\text { INDIKATOR : } \\
\text { INPUT }\end{array}\end{array}$}} & \multicolumn{2}{|c|}{$\begin{array}{c}\text { SD } \\
\text { AKTIF }\end{array}$} & \multicolumn{2}{|c|}{$\begin{array}{c}\text { SD } \\
\text { KURANG } \\
\text { AKTIF } \\
\text { (SALDO } \\
\text { DIBAWA } \\
\text { H 100 rb) } \\
\end{array}$} & \multicolumn{2}{|c|}{$\begin{array}{c}\text { SD } \\
\text { TIDAK } \\
\text { AKTIF } \\
\text { (SALDO } \\
0)\end{array}$} \\
\hline & & $\begin{array}{c}\mathrm{Ad} \\
\mathrm{a}\end{array}$ & 0 & $\begin{array}{c}\mathrm{Ad} \\
\mathrm{a}\end{array}$ & 0 & $\begin{array}{c}\mathrm{Ad} \\
\mathrm{a}\end{array}$ & 0 \\
\hline 1.1 . & Perpustakaan & $\begin{array}{c}10 \\
0 \%\end{array}$ & $0 \%$ & $\begin{array}{c}10 \\
0 \%\end{array}$ & $0 \%$ & $\begin{array}{c}100 \\
\%\end{array}$ & $0 \%$ \\
\hline 1.2 . & Taman & $\begin{array}{l}90 \\
9 \%\end{array}$ & $\begin{array}{c}9,1 \\
\%\end{array}$ & $\begin{array}{l}45 \\
5 \%\end{array}$ & $\begin{array}{l}54 \\
5 \%\end{array}$ & $\begin{array}{l}50 \\
\%\end{array}$ & $\begin{array}{l}50 \\
\%\end{array}$ \\
\hline 1.3 . & Kantin & $\begin{array}{l}72, \\
7 \%\end{array}$ & $\begin{array}{l}27, \\
3 \%\end{array}$ & $\begin{array}{l}18, \\
2 \%\end{array}$ & $\begin{array}{l}81, \\
8 \%\end{array}$ & $\begin{array}{l}33, \\
3 \%\end{array}$ & $\begin{array}{l}66, \\
7 \%\end{array}$ \\
\hline 1.4 . & $\begin{array}{l}\text { Ruang } \\
\text { penyimpanan }\end{array}$ & $\begin{array}{l}72, \\
7 \%\end{array}$ & $\begin{array}{l}27, \\
3 \%\end{array}$ & $\begin{array}{l}63 \\
6 \%\end{array}$ & $\begin{array}{l}36 \\
4 \%\end{array}$ & $\begin{array}{l}50 \\
\%\end{array}$ & $\begin{array}{l}50 \\
\%\end{array}$ \\
\hline 1.3 & $\begin{array}{l}\text { Tempat sampah } \\
\text { Terpisah }\end{array}$ & $\begin{array}{l}81, \\
8 \%\end{array}$ & $\begin{array}{l}18, \\
2 \%\end{array}$ & $\begin{array}{l}27, \\
3 \%\end{array}$ & $\begin{array}{l}72 \\
7 \%\end{array}$ & $\begin{array}{l}33 \\
3 \%\end{array}$ & $\begin{array}{l}66, \\
7 \%\end{array}$ \\
\hline 1.4 . & Kebun & $\begin{array}{l}45 \\
5 \%\end{array}$ & $\begin{array}{l}54, \\
5 \%\end{array}$ & $\begin{array}{l}45, \\
5 \%\end{array}$ & $\begin{array}{l}54 \\
5 \%\end{array}$ & $\begin{array}{l}33 \\
3 \%\end{array}$ & $\begin{array}{l}66, \\
7 \%\end{array}$ \\
\hline 1.5 . & $\begin{array}{l}\text { Koordinator } \\
\text { Lapangan*) }\end{array}$ & $\begin{array}{c}10 \\
0 \% \\
\end{array}$ & $0 \%$ & $\begin{array}{r}10 \\
0 \%\end{array}$ & $0 \%$ & $\begin{array}{c}100 \\
\%\end{array}$ & $0 \%$ \\
\hline
\end{tabular}




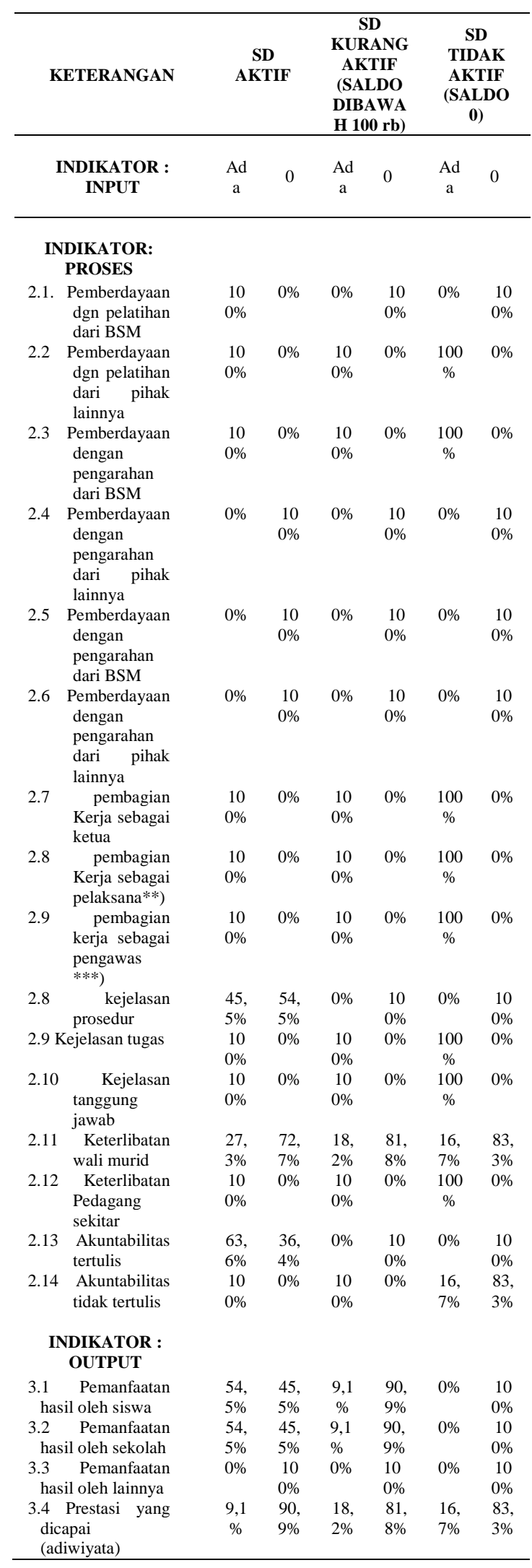

(empiric) yang didasarkan atas analisis pada faktor IPO (Input Proses dan Output) sebagai berikut :

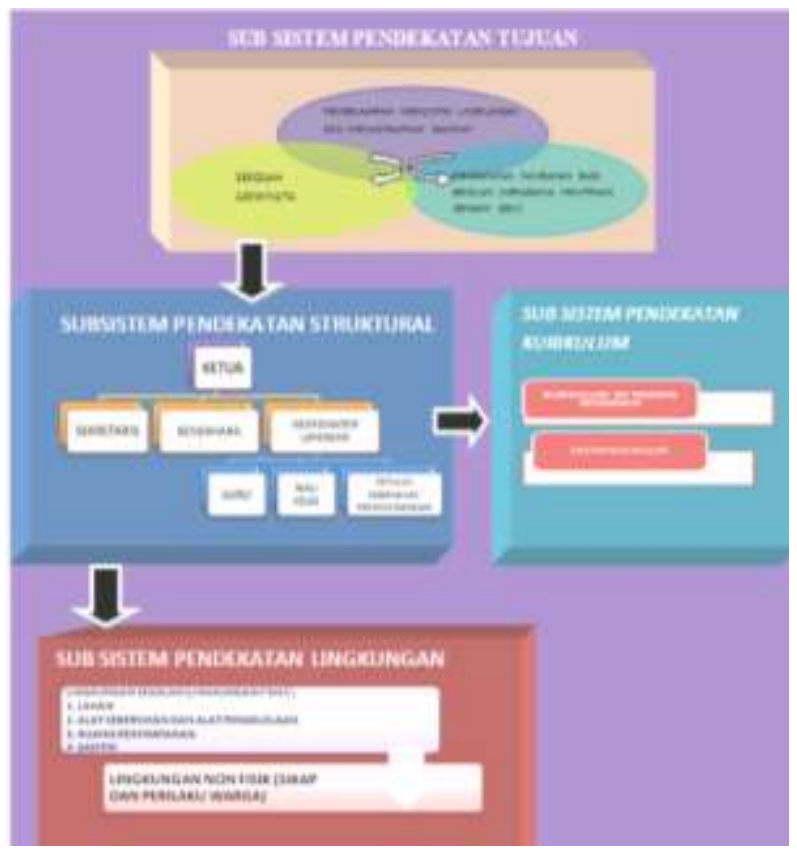

Gambar 3. Model Akselerasi Manajemen Sampah Sekolah Dasar

\section{Uji Statistik Model Manajemen Sampah Sekolah Dasar}

Adapun hasil analisis kenormalan data $\mathrm{O} 1$ (pretest) dan O2(post test) dapat dilihat pada tabel berikut ini :

Tabel 3. Case Processing Summary

\begin{tabular}{lllllll}
\hline \multicolumn{6}{c}{ Casses } \\
\hline & \multicolumn{2}{c}{ Valid } & \multicolumn{2}{c}{ Missing } & Total \\
\hline & N & Percent & N & Percent & N & Percent \\
\hline Pretest & 12 & $100 \%$ & 0 & $0 \%$ & 12 & $100 \%$ \\
\hline Postest & 12 & $100 \%$ & 0 & $0 \%$ & 12 & $100 \%$ \\
\hline
\end{tabular}

Sumber : data diolah

Tabel 4. Tests of Normality

\begin{tabular}{lllllll}
\hline \multicolumn{6}{c}{ Kolmogrov-Smirnov } & \multicolumn{3}{l}{ Shapiro-Walk } \\
\hline & Statistic & Df & Sig & Statistic & Df & Sig \\
\hline Pretest & 0,139 & 12 & 0,200 & 0,965 & 12 & 0,857 \\
\hline Postest & 0,122 & 12 & 0,200 & 0,950 & 12 & 0,634 \\
\hline
\end{tabular}

\section{Desain Model Akselerasi Manajemen Sampah}

Dari situasi yang ada dan hasil curah pendapat serta evaluasi maka terbentuklan model akselerasi manajemen sampah sekolah 


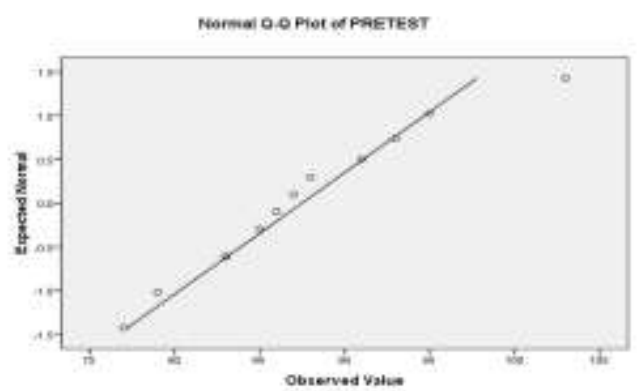

Gambar 4. Q-Q plot pretest

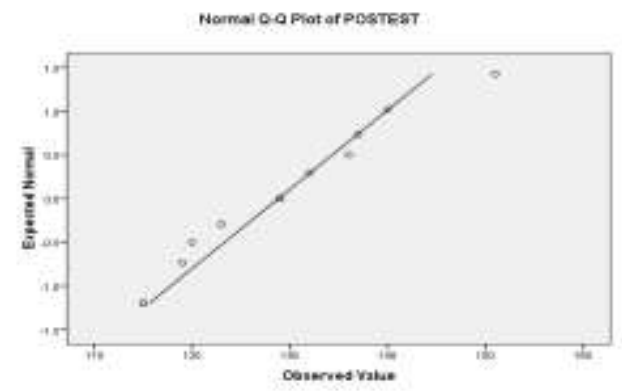

Gambar 5. Q-Q plot postest

Jumlah sekolah yang menjadi sampel penelitian adalah pada 3 Sekolah Dasar dengan 12 pengelola sekolah yang terlibat dalam manajemen sampah yang telah mendapatkan treatment.

Hasil uji normalitas data PRETEST menggunakan statistic uji Shapiro-Wilk (tabel 4) menunjukkan bahwa angka probabilitas pada kolom sig adalah 0,857 yang berarti $>0,05$, maka Ho diterima atau distribusi data pretest mengikuti distribusi normal. Jika dilihat dari plot (grafik pada gambar 4) terlihat bahwa pada grafik Normal Q-Q PLOT PRETEST, data menyebar disekitar garis lurus, maka bisa dikatakan distribusi data normal.

Uji normalitas data POSTEST juga menggunakan statistic uji Shapiro-Wilk. menunjukkan bahwa angka probabilitas pada kolom sig adalah 0,634 yang adalah > 0,05, maka Ho diterima atau distribusi data postest mengikuti distribusi normal. Jika dilihat dari plot (grafik pada gambar 5) terlihat bahwa grafik Normal Q-Q PLOT POSTEST data menyebar disekitar garis lurus, maka bisa dikatakan distribusi data juga normal

Hasil analisis hasil uji Model : Uji dua sample dependen Wilcoxon menunjukkan bahwa angka probabilitas Asymp. Sig adalah 0,002 yang jauh dibawah 0,05, maka Ho ditolak. Hal ini berarti bahwa model efektif untuk peningkatan kegiatan manajemen sampah Sekolah Dasar.

Tabel 5. Ranks

\begin{tabular}{lllll}
\hline & & $\mathrm{N}$ & $\begin{array}{l}\text { Mean } \\
\text { Rank }\end{array}$ & $\begin{array}{l}\text { Sum of } \\
\text { Ranks }\end{array}$ \\
\hline POSTEST - & $\begin{array}{l}\text { Negative } \\
\text { PRETEST }\end{array}$ & $0^{\mathrm{a}}$ & .00 & .00 \\
\hline & Ranks & & & \\
\hline & Positive & $12^{\mathrm{b}}$ & 6.50 & 78.00 \\
& Ties & $0^{\mathrm{c}}$ & & \\
& Total & 12 & & \\
\hline
\end{tabular}

Tabel 6. Uji dua sample -Wilcoxon

\begin{tabular}{cc}
\hline & POSTEST-PRETEST \\
\hline $\mathrm{Z}$ & $3.061^{\mathrm{a}}$ \\
Asymp.sig & .002 \\
\hline a Based of negative rank &
\end{tabular}

Berdasar analisa deskriptif pasca sosialisasi dan pengarahan model manajemen sampah empiric pada 3 Sekolah Dasar ( tabel 2) diperoleh hasil bahwa:

1. Semua Sekolah Dasar memiliki perubahan fisik yaitu penanaman pohon besar didepan sekolah serta terdapat kegiatan manajemen lingkungan. Seperti mengamati tanaman, memberi nama tanaman, memelihara tanaman dan membuat kompos.

2. Semua sekolah memiliki tempat sampah terpisah, yang diletakkan didepan kelas dan satu didalam kelas. Sekolah juga sudah membangun wastafel dibeberapa lokasi. Hal ini penting dilakukan untuk menjaga kebersihan setelah bermain namun juga utamanya setelah mereka memungut sampah yang berserakan baik sampah daun maupun anorganik.

3. Satu sekolah Dasar yang mengalami peningkatan rekening di Bank Sampah namun rekening tersebut tidak atas nama sekolah melainkan atas nama pembersih sekolah. Hal ini memang dikatahui oleh sekolah. Hal tersebut dapat terjadi karena sekolah belum memiliki tempat penyimpanan sampah, sehingga sampah harus dibuang setiap hari. Namun karena 
sampah sudah terpisah (berkualitas) maka bagi pembersih dapat mudah dijual di pemulung / petugas kebersihan untuk kemudian dijual ke BSM. Namun ada pula sekolah yang (petugas kebersihan) sampah anorganiknya dibawa keluar dan ditimbun di ruang penyimpanan diluar sekolah untuk menunggu sampai bank sampah datang mengambilnya.Satu Sekolah sample memang tidak menunjukkan perubahan atas rekeningnya di BSM.

4. Untuk melakukan kegiatan manajemen sampah memang memerlukan ruang untuk melakukan proses recycle (daur ulang: seperti membuat kompos) maupun untuk tempat penyimpanan sampah hingga BSM datang mengambilnya. BSM tidak selalu dapat datang setiap hari bila sampah yang terkumpul hanya sedikit. Sehingga ruang penyimpanan mutlak dalam kegiatan maajemen sampah ini.

5. Membuat siswa dari 'terpaksa' membuang sampah hingga sadar sampah memang membutuhkan komitmen sekolah. Guru harus sering mengingatkan dan menegur siswa agar tidak membiarkan sampah berserakan. Bila ada sampah mereka harus langsung memungutnya dan membuangnya ke tempat yang seharusnya. Satu sekolah sample yang menerapkan dengan cara memberi denda Rp.1000,- yang harus dibayar langsung dari uang jajan siswa pada hari itu. Hal ini untuk membiasakan siswa terhadap kebersihan di lingkungannya. Namun semua sekolah memberikan hadiah bagi kelas-kelas yang bersih dalam lomba kebersihan sekolah.

\section{Model Manajemen Sampah Sekolah Dasar (Model Akhir yang telah teruji)}

Model manajemen sampah Sekolah Dasar ini telah teruji melalui hasil uji statistic sebagaimana diatas. Sehingga atas dasar hal tersebut maka model manajemen sampah empiric telah menjadi model manajemen sampah akhir. Adapun penerapan model sampah tersebut yang ditujukan untuk akselerasi kegiatan manajemen sampah di sekolah memiliki prinsip dan dasar pelaksanaan kegiatan sebagai berikut :

Prinsip dasar model akselerasi manajemen sampah bagi Sekolah Dasar adalah partisipatif dan berkelanjutan. Partisipatif artinya bahwa kegiatan ini memerlukan gotong royong dan kerjasama antara pihak guru, murid, dan tenaga dilapangan. Sehingga semua komunitas sekolah terlibat dalam manajemen sampah sekolah yang meliputi keseluruhan proses perencanaan, pelaksanaan dan evaluasi sesuai dengan tanggung jawab dan peran masingmasing. Keberlanjutan artinya bahwa kegiatan ini harus memiliki komitmen untuk selalu diselenggarakan terus menerus sehingga kegiatan manajemen sampah ini memerlukan program yang meresap kedalam kurikulum disekolah.

\section{Pendekatan Sistem}

Pendekatan sistem yang digunakan dalam model ini bermaksud untuk memandang sekolah sebagai satu kesatuan yang terdiri dari subsistem-subsistem yang saling berhubungan dan saling bergantung. Didalam masing-masing subsistem terdiri dari beberapa elemen yang apabila mereka berinteraksi maka akan membentuk satu kesatuan yang menyeluruh. Sebagai sebuah sistem dalam manajemen sampah sekolah, maka sistem ini terdiri subsistem pendekatan Tujuan, subsistem pendekatan organisasi, subsistem pendekatan lingkungan (fisik dan non fisik) serta subsistem kurikulum.

\section{Sub sistem Pendekatan Tujuan}

Pendekatan tujuan adalah suatu pendekatan tentang perwujudan dari suatu keadaan yang diinginkan dimana sekolah bermaksud untuk merealisasikannya. Pendekatan tujuan berisi pernyataan tentang keadaan atau situasi yang tidak terdapat sekarang tetapi dimaksudkan untuk dicapai melalui kegiatan-kegiatan sekolah. Sehingga terdapat dua unsur dalam pendekatan tujuan yaitu 1) hasil-hasil akhir yang diinginkan diwaktu yang akan datang dengan mana 2) kegiatan-kegiatan diarahkan. 
Subsistem pendekatan Tujuan merupakan tahapan paling kritis dalam proses perencanaan kegiatan. Pendekatan tujuan yang akan dipilih akan menentukan kegiatan dan mengikat sumberdayasumberdaya sekolah untuk jangka waktu yang panjang. Karena alasan inilah, maka tujuan yang ditetapkan telah mempertimbangkan sejumlah alternatif tujuan lainnya. Subsistem pendekatan tujuan untuk manajemen sampah sekolah dasar ini terdapat 3 pilihan tujuan yang menyatu sebagaimana dalam gambar.

Pembelajaran pada siswa untuk mencintai lingkungan dan memanfaatkan sampah menjadi tujuan pertama karena tujuan ini akan tercapai jika didukung oleh program kegiatan yang jelas dan konsistensi yang berarti bahwa harus memasukkan dalam kurikulum sekolah. Kemudian hasil yang nyata dari keberhasilan pembelajaran adalah lingkungan yang bersih, asri, nyaman dan sehat. Adanya kurikulum yang memasukkan tentang lingkungan berikut kegiatannya adalah juga merupakan syarat yang mampu dipenuhi untuk menjadi sekolah adiwiyata. Disamping itu atas hasil kemitraannya dengan BSM akan diperolah pendapat yang berguna bagi berbagai kegiatan siswa (sekolah). Hal ini merupakan alat memperkuat mengapa kegiatan ini harus terus berkelanjutan.

Jika sekolah memilih pendekatan tujuan pertama adalah adiwiyata, sehingga kemudian mereka .membuat kurikulum pembelajaran untuk mencintai lingkungan dan memanfaatkan sampah tanpa melakukan kemitraan dengan BSM, maka hal ini yang kemudian membuat sekolah kemudian turun semangatnya sedikit demi sedikit dalam perhatiannya terhadap lingkungan. Mereka puas dengan adiwiyata yang telah dicapai maka selesailah tugas bagi sekolah. Sekolah yang bersih dan rindang dianggap sudah cukup. Sehingga pilihan pendekatan ini akan berhenti dalam jangka waktu tertentu. Padahal setelah memperoleh adiwiyata maka sekolah dapat lebih mengembangkan diri dengan program-program barunya yang lebih menarik sehingga menimbulkan semangat cinta lingkungan yang tidak pernah pupus. Bukan hanya memelihara lingkungan tapi melakukan recycle sampah juga membutuhkan ide-ide menantang yang yang tentu saja harus didukung dengan hasil nyata lainnya.Jika sekolah memilih pendekatan pertama adalah kemitraan dengan BSM baru kemudian menyusun program pembelajaran maka yang terjadi adalah berhentinya kemitraan karena beban yang terlalu banyak. Sehingga pilihan ini dalam kenyataannya tidak akan memaksimalkan prestasi

\section{Sub Sistem Pendekatan Struktural}

Sekolah merupakan suatu organisasi yang memiliki struktur organisasi dengan karkteristiknya masing-masing. Program kegiatan yang memerlukan partisipasi dan berkelanjutan membutuhkan pembagian pekerjaan. Pembagian kerja dapat dilakukan melalui aliran tugas dalam stukrtur organisasi. Subsistem pendekatan struktural ini dimaksudkan untuk memperbaiki prestasi khususnya dalam hal manajemen sampah di sekolah melalui prinsip prinsip perancangan struktur organisasi sekolah, dimana perumusan secara jelas terhadap tugas, tanggung jawab dan pembagian kerja dan garis wewenang yang tepat. menjadi hal utama. Sebagai contoh tugas dan tanggung jawab terkait dengan manajemen sampah sekolah secara terperinci adalah sebagai berikut:

\section{Ketua}

Ketua mempunyai tugas dan tanggung jawab : 1) Melakukan kerjasama dengan BSM, 2) Menetapkan koordinator lapangan sebagai lingkungan hidup dan manajemen sampah, 3) Menyediakan fasilitas pembelajaran tentang lingkungan dan manajemen sampah, 4) Melakukan monitoring kegiatan lingkungan maupun manajemen sampah disekolah, 5) Melakukan kerjasama kemitraan dengan instansi terkait untuk memperoleh berbagai pelatihan bagi guru yang akan diteruskan kepada siswa 


\section{Bendahara}

Bendahara adalah seorang wakil kepala sekolah atau guru yang ditunjuk khusus : 1) Melakukan administrasi keuangan dalam kaitannya dengan BSM, 2) Melaporkan kondisi keuangan dan rencana lanjutan atas kegiatan manajemen sampah sekolah

\section{Petugas Lapangan}

Untuk mengoptimalkan aliran kerja, pembagian kerja bagi petugas lapangan dalam model ini menggunakan pendekatan desentralisasi. Karena pendekatan desentralisasi dapat meningkatkan kinerja dan kreativitas anggota. Petugas lapangan terdiri dari seorang koordinator lapangan yang dapat berasal dari seorang guru yang khusus menangani hal ini atau seorang karyawan yang khusus menangani lingkungan dan manajemen sampah. Mengingat kegiatan manajemen sampah tidak hanya mengumpulkan sampah tetapi juga merencanakan kegiatan pengolahan sampai penggunaan dan kegiatan ekonomisnya serta mencari ide-ide kreatif untuk memanfaatkan sampah.

\section{Guru}

Tugas dan tanggung jawab : 1) Membuat rancangan proses pembelajaran sesuai kelas dan bidangnya masing-masing (sebagai mana dalam contoh sub sistem pendekatan kurikulum), 2) Membuat program kegiatan ekstrakulikuler recycle sampah

\section{Walikelas}

Tugas dan tanggung jawab : 1) Membuat jadwal piket kelas ,2) Membentuk kader lingkungan (kader kebersihan), 3) Mengajar cara pembuatan kompos, 4) Membuat daftar petugas pembuat kompos secara bergantian

\section{Petugas kebersihan/petugas taman}

Petugas kebersihan/petugas taman : bertugas 1) Melakukan hubungan dengan BSM, 2) Membantu guru dan siswa cara pembuatan kompos

\section{Sub Sistem Pendekatan Kurikulum \\ Kurikulum SD Tematik Integratif}

Filosofi pendidikan kurikulum 2013 mendasarkan pada pendidikan yang berakar pada budaya bangsa. Hal ini untuk membangun kehidupan bangsa masa kini dan masa mendatang. Mempersiapkan peserta didik untuk masa depan selalu menjadi kepedulian kurikulum, hal ini mengandung makna bahwa kurikulum adalah rancangan pendidikan untuk mempersiapkan generasi muda bangsa. Dengan demikian, tugas mempersiapkan generasi muda menjadi tugas utama suatu kurikulum. Kurikulum 2013 bagi siswa SD yaitu kurikulum integratif merupakan salah satu langkah maju untuk pengintegrasian pendidikan manajemen sampah dan lingkungan hidup di sekolah. Cara pengintegrasian tersebut dimulai dari menganalisis kemampuan/sub kemampuan setiap keahlian/program keahian sampai menghasilkan suatu materi kejuruan yang berkaitan. Keterlibatan pendidik dalam menumbuhkan situasi belajar yang kondusif bagi peserta didik untuk belajar meliputi upaya menciptakan iklim belajar yang partisipatif. Beberapa contoh memasukkan manajemen sampah dalam matapelajaran Sekolah Dasar (tematik integratif) kelas IV dan kelas V

\section{Contoh 4 : Jaringan Tematik Integratif SD kelas IV}

Matematika bermakna jika menyambung dengan kehidupan. Maka proses kegiatan untuk pembelajaran sebagai berikut :

1. Diawali dengan mengenal penjumlahan bilangan ratusan dan latihan

2. Pengenalan mengenai timbangan, bagaimana cara menggunakannya dan menimbang berbagai berat benda seperti berat kertas bekas (dalam kg dan ons)

3. Menghitung jumlah benda dan ditimbang dalam satuan berat. (misal :untuk menjawab berapa benda yang dibutuhkan dalam satu kg?)

4. Berapa jumlah rupiah yang akan diterima jika benda tersebut di kumpulkan dan 
dijual kembali (penjumlahan dan perkalian)

5. Melakukan jajak pendapat tentang makanan kesukaan (coklat atau permen atau roti, kacang hijau)kepada para murid. Buat polling jajak pendapat dan grafik

6. Memberi hadiah makanan kesukaan apabila siswa berhasil (mendapat nilai 100) untuk melakukan penjumlahan dan perkalian sebagai evaluasi hasil mata pelajaran.

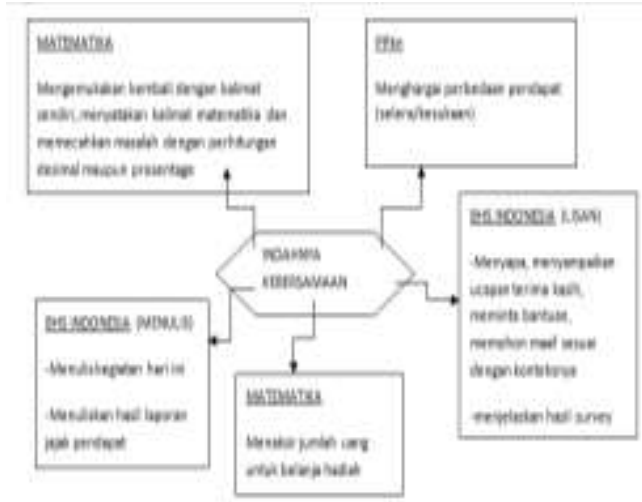

Gambar 6 Jaringan tematik integratif SD kelas IV

\section{Contoh 5 Jaringanan Tematik Integratif SD kelas V}

Proses pelaksanaan pembelajaran dilakukan dengan menaksir dana yang dibutuhkan untuk amal.

1. Membuat barang dr daur ulang (recycle)

2. Mencari gagasan untuk membuat produk dari bahan daur ulang (recycle)

3. Menceritakan gagasan dan membentuk kelompok

4. Membuat barang dari bahan recycle dengan bekerja sama membuat kompos

5. Membuat kompos dan membungkus kompos dengan menimbang

6. Mencari informasi harga kompos (Survey harga kompos)

7. Melakukan penjualan atas barang hasil recycle dan kompos

8. Menghitung biaya pembuatan barang recycle dan kompos

9. Menetapkan harga jual

10. Menghitung hasil usaha untuk amal

11. Membuat laporan tertulis tentang kegiatan dan hasil yang diperoleh

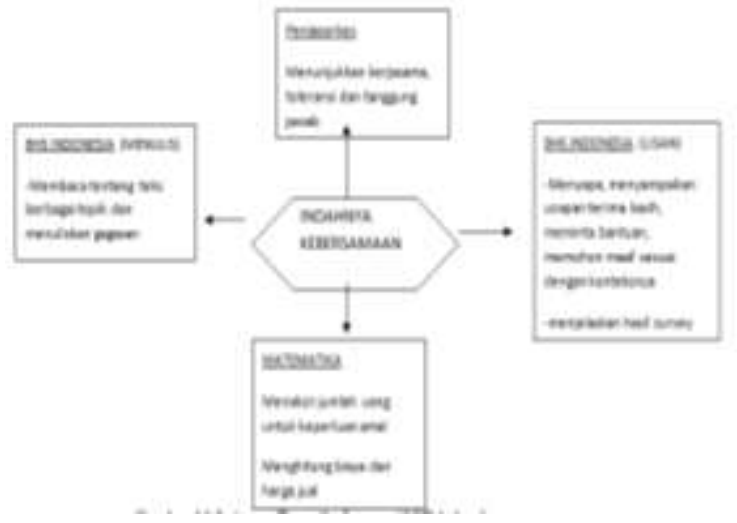

Gambar 7. Jaringan tematik integrative SD kelas V

\section{Ekstrakulikuler}

Pelaksanaan pengintegrasian materi manajemen sampah dan lingkungan hidup pada kegiatan ektrakurikuler dapat memilih metode dan media sesuai dengan kondisi lapangan. Kegiatan ini diarahkan untuk membentuk sikap dan perilaku siswa dalam mewujudkan pembangunan yang berkelanjutan. Kegiatan ekstrakurikuler seperti $7 \mathrm{~K}$ yang mencakup keamanan, ketertiban, kebersihan, keindahan, kekeluargaan, kerindangan, dan kesehatan merupakan suatu wadah yang dapat dimanfaatkan untuk menyampaikan materi lingkungan kepada siswa dalam kegiatan konkret. Kegiatan konkret tersebut dapat dilakukan pada :1) Pembuatan piket kebersihan kelas dan halaman depan kelas bagi semua kelas, 2)Membuat kader lingkungan bagi siswa kelas IV dan V, 3)Pembuatan piket dengan BSM (pada kader lingkungan) untuk menjaga kebersihan sekolah dan kantin dengan tugas mengumpulkan sampah kering (kertas dan botol) di karung bagi siswa kelas IV dan kelas V.

\section{Sub Sistem Pendekatan Lingkungan Lingkungan Fisik}

Sumber daya lahan adalah segala sesuatu yang bisa memberikan manfaat di lingkungan fisik dimana meliputi tanah, iklim, relief, hidrologi dan vegetasi yang ada. Dari semua faktor yang ada tersebut dapat mempengaruhi potensi dalam penggunaan lahannya, termasuk di dalamnya adalah 
akibat dari kegiatan-kegiatan manusia baik di masa lalu maupun masa sekarang.

Lingkungan fisik dalam model ini meliputi : lahan untuk pepohonan,alat kebersihan dan alat pengelolaan, ruang penyimpanan dan kantin. Lingkungan fisik ini akan mendukung kegiatan manajemen sampah disekolah.

1. Lahan

Adanya lahan yang cukup luas memang sangat membantu untuk manajemen sampah yang dilakukan. Kompos yang dibuat dari sampah basah termasuk sampah organic (dari dedaunan) dapat digunakan lagi pada lahan sekolah. Siswa dapat belajar menanam, dan memelihara tanaman. Sekolah dapat menjadi Green school. Tanaman yang dipilih dapat berjenis tanaman hias, pohon ataupun tanaman apotek hidup yang akan berguna untuk pelajaran lainnya. Misalkan menanam tomat, yang hasilnya dapat digunakan sebagai matapelajaran kewirausahaan pada siswa kelas VI. Menanam apotik hidup dan pembelajaran tentang memanfaatkan apotik hidup juga baik untuk dilakukan.

2. Alat Kebersihan dan Alat Pengelolaan

Terdapat berbagai alat kebersihan sekolah seperti sapu lidi, plastik sampah, tempat sampah, tong sampah dan lain-lain. Namun alat kebersihan sekolah yang perlu mendapat perhatian disini adalah keadaan tempat sampah sekolah. Dalam model ini menyarankan agar tempat sampah yang digunakan adalah tempat sampah yang terpisah antara sampah basah, sampah kering dan sampah organik (dari sampah tanaman). Hal ini untuk menghindari proses pemilahan dan agar sampah yang dihasilkan masih memiliki nilai ekonomi yang tinggi. Sampah kertas dan plastik bekas sisa makanan dapat dibuang di tempat sampah kering. Sedangkan sampah kantin dan sisa makanan dimasukkan pada tempat sampah basah. Sedangkan sampah dedaunan dimasukkan kedalam sampah organik. Siswa tidak disarankan melakukan pemilahan sampah kecuali meletakkan sampah sesuai dengan tempatnya.

3. Ruang Penyimpanan

Ruang penyimpanan diperlukan untuk menyimpan sampah yang belum terangkut oleh BSM. Hal ini terjadi karena banyaknya sampah yang dihasilkan sekolah belum cukup untuk diangkut BSM keliling karena hanya sampai yang baik saja yang dikelola sekolah selebihnya menjadi bagian dari pemulung yang ada disekitar sekolah. Ruang penyimpanan ini merupakan syarat utama dari lingkungan fisik agar manajemen sampah berhasil. Tentu saja ruang ini tidak perlu besar namun diperlukan agar sampah tidak terkena panas dan tidak menggangu pemandangan.

4. Kantin

Kantin sekolah adalah tempat yang paing besar menghasilkan sampah basah. Oleh karena itu dalam kurikulum sekolah dalam matapelajaran lingkungan kantin adalah tempat yang harus bersih dari sampah. Pembuangan sisa sampah kantin tidak disarankan untuk dikelola oleh siswa dalam kegiatan manajemen sampah namun sampah kantin harus benar-benar dibuang sesuai tempatnya. Siswa hanya disarankan sebagai kader kebersihan yang mengingatkan pengelola kantin untuk menjaga kebersihan dari sampah yang berserakan.

\section{Lingkungan Non Fisik (Sikap dan Perilaku Warga)}

Lingkungan non fisik dalam hal ini meliputi sikap dan perilaku warga. Sikap dan perilaku warga sekolah terhadap lingkungan hidup merupakan nilai yang paling penting dalam mewujudkan kelancaran manajemen sampah sekolah. Pelaksanaan manajemen sampah disekolah mempunyai sasaran meningkatkan kepedulian seluruh warga sekolah (kepala sekolah, karyawan, guru, dan siswa) terhadap lingkungan.Sikap dan perilaku warga sekolah dapat dibentuk atau dimodifikasi dengan hukum pengaruh (law of effect) ; yang menyatakan bahwa perilaku yang diikuti konsekuensi-konsekuensi 
pemuasan cenderung diulang, sedangkan perilaku yang diikuti konsekuensikonsekuensi hukuman cenderung tidak diulang. Proses pembentukan perilaku ini secara sederhana dapat digambarkan sebagai berikut :

Rangsangan $\rightarrow$ tanggapan $\rightarrow$ konsekuensikonsekuensi $\rightarrow$ Tanggapan diwaktu yang akan datang

Gambar 6. Siklus pembentukan perilaku

Sebagai contoh untuk menilai sikap dan perilaku siswa dengan kategori rajin atau malas. Salah satunya dapat dilihat dari penampilan kelasnya. Jika kelas siswa kelihatan kotor, apakah akibat banyak kertas berserakan dan banyak coretan di dinding, kelasnya dapat dinilai bahwa siswa tersebut belum memiliki kepedulian terhadap sampah. Demikian juga bagi guru, tenaga administrasi, dan kepala sekolah dapat dinilai dari ruang kerja masing-masing unit, jika tampak berserakan kertas maka mereka belum memiliki kepedulian terhadap lingkungan. Yang mendapatkan penilaian baik dapat diberikan penghargaan, namun perilaku yang buruk dapat diberikan peringatan sampai dengan hukuman.

Namun sebagai catatan adalah bahwa sebagian penelitian menemukan bahwa untuk perubahan perilaku yang lebih efektif adalah dengan memberikan penghargaan atas perilaku yang diinginkan dibandingkan hukuman bagi perilaku yang tidak diinginkan. Penghargaan yang dapat diberikan oleh sekolah baik bagi siswa sampai dengan para guru tidak selalu harus bernilai ekonomi. Pujian yang disampaikan pada saat upacara, ucapan terima kasih yang diberikan didepan orang banyak, piagam keteladanan yang diberikan pada saat saat tertentu serta makan ringan bersama (kacang hijau) dengan siswa ketika tujuan berhasil dan hadiah hadiah kecil lainnya (coklat atau makanan kesukaan bagi siswa, pin) bisa dilakukan. Mengadakan kegiatan lomba penghijauan dan kebersihan bagi siswa juga merupakan kegiatan yang disarankan.
Memelihara komunikasi dengan baik dengan warga sekolah termasuk orang tua siswa serta melibatkan mereka pada beberapa keputusan juga merupakan bentuk penghargaan yang disarankan agar orang tua juga mendukung kegiatan peduli lingkungan dan sampah yang diberikan kepada siswa. Sedangkan bagi warga sekolah seperti pedagang makanan, warung, pemilik/pengurus kantin sekolah merupakan elemen yang harus mendapatkan perhatian pula karena tingkat sampah yang mereka hasilkan relatif banyak. Kerjasama dan komunikasi untuk sadar kebersihan merupakan tanggung jawab mereka terhadap keberadaanya di lingkungan sekolah.

\section{KESIMPULAN DAN SARAN}

Metode penelitian untuk mendesain model akselerasi manajemen sampah ini adalah dengan metode kualitatif dengan analisa IPO (Input, Proses, Output) kemudian diterjemahkan dalam Model Manajemen Sampah Sekolah Dasar. Secara garis Desain model yang dihasilkan terdiri dari sub sistem pendekatan lingkungan, sub sistem pendekatan struktural, sub sistem pendekatan kurikulum dan sub sistem pendekatan lingkungan (baik fisik maupun non fisik. Model yang dibangun tersebut diimplementasikan kepada 3 Sekolah Dasar. Uji statistik dilakukan dengan membandingkan antara hasil pretest $(\mathrm{O} 1)$ dan hasil Postest $(\mathrm{O} 2)$ setelah treatment dilakukan (model Quasi). Tahap selanjutnya dilakukan Uji statistik dengan uji sample berpasangan Wilcoxon. Hasil pengujian terhadap model Manajemen sampah sekolah dasar menunjukkan angka exact sig sebesar 0,002. Ini menunjukkan bahwa model yang dibuat efektif untuk peningkatan kegiatan manajemen sampah di Sekolah Dasar. Secara deskriptif (data kualitatif) penerapan model ini di sekolah Dasar menunjukkan bahwa Sekolah Dasar memiliki tampilan fisik yang lebih rindang karena mulai memperhatikan penghijauan disekolah, sudah memiliki tempat sampah yang terpisah yang berada dimasing-masing kelas serta memiliki tempat mencuci tangan (wastafel) di depan kelas. Namun rekening sekolah tidak menunjukkan 
data yang signifikan atau meningkat karena beberapa hal, yaitu : Pertama, Sekolah masih dalam proses melakukan kegiatan sadar akan sampah yaitu dengan kegiatan membiasakan siswa membuang sampah sesuai tempatnya. Kedua, kegiatan membuang sampah sesuai tempatnya ternyata digunakan oleh pembersih untuk meningkatkan pendapatannya (bukan nama sekolah). Ketiga, kegiatan manajemen sampah membutuhkan suatu ruang penyimpanan khusus agar sampah tidak merusak pemandangan sebelum diambil oleh BSM. Hal ini memerlukan dana tersendiri yang harus dianggarkan oleh sekolah.

\section{Saran}

1. Bagi Bank Sampah Malang: banyak aktivitas dan kreativitas yang dilakukan BSM dalam mendaur ulang sampah. Dokumentasi kegiatan tersebut sebaiknya dapat diberikan kepada sekolah yang menjadi binaan untuk menjadi inspirasi di sekolah. Seperti pemanfaatan sampah sebagai pembuatan minyak (BBM), pembuatan batu bara, dan lain sebagainya.

2. Bagi Pemerintah (Diknas): mengadakan lomba yang sejenis dengan adiwiyata misalnya duta sampah dan lomba guru yang kreatif dengan berbasis lingkungan dan lomba sekolah hijau

3. Bagi Peneliti Lain: peneliti lain yang ingin meneliti serupa tentang manajemen sampah, diharapkan dapat lebih mengembangkan model akselerasi manajemen sampah ini untuk sekolah diluar Kota Malang dengan prosedur yang mungkin berbeda dengan bank sampah Malang.

\section{DAFTAR PUSTAKA}

Affan, Satrian. 2009. Peran Universitas Dalam Pengelolaan Sampah. http://suarapembaca.detik.com/read/20 09/06/04/102154/1142480/471/peran universitas-dalam-pengelolaansampah.html [17 Maret 2010].
Arni, Noni Arni. 2009. Bank Sampah Mengubah Pandangan tentang Sampah. Penerbit: Sosial Budaya.

Bararah, Vera. 2010. Sampah Hilang Uang Datang di Bank Sampah. Penerbit: detik Health, Diakses 12 Februari 2014

Ceplas Ceplos. 2008. Peluang dari Gelas Plastik. thread-42257.html. Diakses 15 Oktober 20013

Eny Prihtiyani. 2009. Gerakan Bank Sampah dari Bantul. Penerbit: Kompas. Diakses tanggal November 2013)

Ghofur, Abdul 2009. Manusia Gerobak: Kajian Mengenai Taktik-taktik Pemulungjatinegara di Tengah Kemiskinan Kota. Penerbit: Lembaga Penelitian Semeru. Diakses April 2013

Hasanah,Iffah. 2009. Hidup Nyaman di Lingkungan yang 'Aman'. http://majalahnh.com/index.php/liputan /132-hidup-nyaman-di-lingkunganyang-aman.html Diakses November 2013

Kementrian Lingkungan Hidup (adiwiyata). http://www.menlh.go.id/adiwiyata/\#sth ash.v7nRbHCc.dpuf

Meirik, Karen. Kertas Bekas Tidak Menguntungkan Lagi. 2009. http://static.rnw.nl/migratie/www.ranes i.nl/arsipaktua/asiapasifik/cina_barat22 0309-redirected 22 diakses Oktober 2013.

Kulang, Kusni . 2009. Perda Sampah (dalam Jurnal Toddoppuli tentang Cerita Untuk Andriani S. Kusni \& AnakAnakku). Palangkaraya, 11 November 2009

Tawarkan Konsep Bank Sampah Bisa Diterapkan di Sekolah. Fakultas Kehutanan Universita Mulawarman http://www.kaltimpost.web.id/index.ph p? mib=berita. detail\&id $=35974$

Kompas, 2 Juni 2010. Menabung di Bank Sampah.

Mangkara.S.B,Hafida,et.al,2011.Penerapan sistem pengelolaan sampah kota dengan pemberdayaan fungsi TPS sebagai solusi pengurangan timbunan sampah di TPA kota Surakarta.Surakarta 
Noni, Arni. 2009. Bank Sampah Mengubah Pandangan tentang Sampah. Penerbit: Sosial Budaya.

Panduan Pelaksanaan Pendidikan Karakter, Pusat Kurikulum dan Perbukuan, 2011

Peraturan Menteri pendidikan dan Kebudayaan no 67 TAHUN 2013 tentang kerangka dasar dan struktur kurikulum sekolah dasar/madrasah ibtidaiyah

Pertama Di Dunia Bank Sampah Indonesia. 2009. Ditulis dalam Motivasi. Diakses April 2013

Transaksi sampah dan Jumlah .Bank sampah Malang.Http://banksampah.org.

(November

www.sekolahdasar.net/2012/12/metod e-tematik-integratif-pada.html.

Metode tematik Integratif sekolah dasar.

Menggagas sekolah berwawasan lingkungan. Lingkungan adiwiyata.blogspot.com 2011.Diakses

Mei 2013 